\title{
Mediterranean Vegetation in Anglophone Literature as a Sign of Man's Relationship with the World
}

\author{
By Françoise Besson*
}

\begin{abstract}
Mediterranean vegetation gives a sign of a necessary dialogue between people who are united by plants having their origins in the Mediterranean world. It becomes the visible and colourful sign of a dialogue between man and the non-human, which reveals man's place in the world. From Shakespeare to Laurence Durrell, N. Scott Momaday, Mahmoud Darwish, Niyi Osundare and Wangari Maathai, this paper will try to show how Mediterranean plants in Anglophone literature are the sign of man's relationship with the world and point to the conclusions that may be drawn from a combined reading of nature and history.
\end{abstract}

Keywords: Colonization, Deforestation, Mediterranean, Poetry, Vegetation.

Vegetation at large appears in poems, novels or essays in English as the sign of man's relationship with the world and of a necessary combined reading of nature and history. The reed in which the pipe is made in Blake's Introduction to the Songs of Innocence (1982), by echoing the verb "to read", suggests that we are invited to read nature. More specifically Mediterranean plants, perhaps because they are the natural sign of the influence of classical culture on the western world, perhaps because they are situated in an original space-Biblical lands, Greece, Rome or Egypt-, speak about man's relationship with nature and the world.

Why choose only Mediterranean plants? The authors using plants as metaphors, symbols, or mere reality, do not randomly choose some of the most well-known ones, like olive-trees or orange-trees, and they clearly want to bring a Mediterranean sign into their texts. It is perhaps less obvious when an author evokes carnations, which happen to be originally Mediterranean, but are probably used more because of their symbolism than for their geographical origins, as we see with Shakespeare's use of this flower. The observation of Mediterranean vegetation in Anglophone literary texts is not merely a stylistic study meant to make a list of Mediterranean plants in literary texts. It has a deeper role and throws light on a half-hidden ecocritical dimension of texts, which do not seem at first sight to be ecological ones; it may also show how some authors, in an original way, speak about colonization merely through the transfer of plants from the Mediterranean Basin to the American continent. If Mediterranean plants are chosen more often than others, it is perhaps because they are a "parable of

${ }^{*}$ Professor, University of Toulouse 2-Jean Jaurès, France. 
the human experience" (Kunitz 2005) ${ }^{1}$ evoking the cradle of mankind and the interrelation of all spaces suggesting a "utopian and concrete garden" (Serres 1974). ${ }^{2}$ The first plants mentioned have appeared in the Mediterranean area since, as Michel Baridon underlines, "according to the Old Testament, Adam appears as the founder of the first botanical garden as he gave each plant in the Garden of Eden a name" (Baridon 1998: 40). Those plants were Mediterranean ones and so it is not by chance if so many Mediterranean plants appear in world literature and particularly Anglophone literature. A few examples of those botanical mentions will show the multiple roles of Mediterranean vegetation in Anglophone literature. Mediterranean vegetation suggests a necessary dialogue between people united by plants having their origins in the Mediterranean Basin. It becomes the visible and colourful sign of a dialogue between man and the nonhuman, which reveals man's place in the world; this apparently ornamental device is in fact a way of leading readers to a sense of responsibility.

\section{Mediterranean Plants in Shakespeare's Plays as a Reflection of Man's Fate}

Nature imagery in Shakespeare's plays and particularly the mention of Mediterranean plants, is significant. Yet the first work ever published by Shakespeare, Venus and Adonis, even if it is situated in a Mediterranean context since it tells the story of a Roman mythological couple, and the non human world, either animal or vegetal, plays an important role in the poem, it refers mostly to flowers and plants in general than to specific Mediterranean species. General vegetation is there to speak about life and death and about a relationship of reciprocity between the characters and the earth: "Upon the earth's increase why should thou fed, / Unless the earth with thy increase be fed?" (Venus and Adonis 1. 169-170). It is only at the end that Mediterranean vegetation appears with a real "myrtle grove" (ibid: 865 ) that is part of the setting and a metaphorical "ebon dart" designating death (ibid: 948). The non human world at large seems to speak about man's relationship with the earth through two mythological characters, the non human world rooting their story in the reality of the earth. But it is chiefly in the plays that Mediterranean vegetation is more present. In The Winter's Tale, a play partly situated in Sicily, Perdita says:

Sir, the year growing ancient, not yet on summer's death, nor on the birth

\footnotetext{
${ }^{1}$ The poet Stanley Kunitz speaks about "the lifespan of a flowering plant [.... [as] a compressed parable of the human experience" (14).

2 "Those who take care of plants and animals, name them, classify them, and constitute that utopian space and ground where intervals tend towards zero, where the Australian monotreme grows side by side with Jan Mayen's lichens as on the pages of a book. Theorem: to each classification there corresponds a utopian and concrete ground" (Serres 1974:151, author's translation).
} 
Of trembling winter, the fairest flowers of the season

Are our carnations, and streaked gillyvors,

Which some call nature's bastards. Of that kind

Our rustic garden is barren, and I care not to get slips of them (IV, iv, 79-82)

Carnations originally grew in the Mediterranean basin, and gillyflower is a name first given in Italy to all pink flowers. An encyclopaedia online notes that "The gillyflower of Chaucer and Spenser and Shakespeare was, as in Italy, Dianthus Caryophyllus" (Library Index n.d), which is a carnation. The flowers were probably chosen by Shakespeare mostly because they were called by some "nature's bastards" than for their Mediterranean origin, but the fact is that the organic rhythm of seasons is seen through the evocation of the two flowers. The carnation and gillyflower are rejected by Perdita as non-seasonal flowers associated with "bastardy", because she saw in that recreated nature, the image of her life as a foundling. Some even see in this allusion to "horticultural problems connected with variations" a foreshadowing of Darwin's theories. Bacon, in Sylva Sylvarum (1627), mentioned those horticultural experiments: "We are no longer left sidetracked in the environment, but face to face with the truth that nature contains the secret of its own evolution" (Evans and Leyris 1957, Sh. Eng. I $515)^{3}$. The character's fate and the history of nature's evolution both appear in the mention of two flowers.

Through the yellow iris, or "flower-de-luce" mentioned in The Winter's Tale and Henry $V$-where it becomes a love word-, a plant chosen by king Louis VII as "the emblem on his shield and banner when he went to his first Crusade" (Kerr 1997: 31), love and war are linked in a flower evoking the Crusades and the medieval Mediterranean religious battlefield. In The Winter's Tale again, when Perdita speaks about violets, she links them with Antiquity, through Roman mythology and Greek customs: "Violets dim, but sweeter than the lids of Juno's eyes" (IV, iv, 120-121). In ancient Greece, "the custom among women [was to paint][...] their eyelids with a purple, sweet-scented ointment" ${ }^{4}$. Through the double metaphor uniting nature and mythology, together with the double cultural reference to Rome through Juno and to Greece and through the make-up custom, Shakespeare suggests a link between nature and myths in the Mediterranean world reconstituted in a flower. Violets have been grown in the Mediterranean Basin since High Antiquity. Athenians used to buy bunches of violets as early as $400 \mathrm{BC}$ and made creams or teas with them, whereas Romans made crowns with them to make headaches disappear. The Mediterranean rosemary appears several times in Shakespeare's plays, in Hamlet and The Winter's Tale, to convey remembrance. The Winter's Tale also contains references to "lavender, mints, savory, marjoram" (Ibid.). The typically Mediterranean hot lavender and savory perhaps "brought to England by the Roman invaders" (Kerr 1997: 59), change the war memory into a painting of the profusion of nature

\footnotetext{
${ }^{3}$ Note in The Works of Shakespeare, vol. 11, 806.

${ }^{4}$ See http://bit.ly/2ax4Csh. [Accessed 7 February 2016].
} 
conveyed by the list. Flowers in Shakespeare's theatre introduce soft nature into the wild world of men's violence. The Mediterranean origins of some of those plants metaphorically place Man in a natural world where the innocence symbolized by flowers is superimposed on the memories of violence (Crusades, Roman invasion...) suggesting a world where everything is interrelated to build up man's fate.

\section{Poetry in English and the Mediterranean Vegetable World: From Satire to Ecology}

In 1713, Alexander Pope, the great poet praising the Enlightenment and religious tolerance among other values, wrote a satirical essay on topiary art in which he described the catalogue of a correspondent, which takes the form of a gallery of funny vegetable portraits: "Edward the Black Prince in cypress, /A Laurustine Bear in Blossom with a Juniper Hunter in Berries, /A Queen Elizabeth in Phyllirea, a little inclining to the green sickness, but of full growth. /Another Queen Elizabeth in Myrtle, which was very forward, but miscarried by being too near a Savine. / [...] A topping Ben Johnson in Laurel, / Divers eminent poets in Bay, somewhat blighted, to be disposed of a pennyworth" (Pope 1713, Baridon 1998). This strange list draws its humour from the telescoping between famous historical characters or poets and Mediterranean plants. The technical characteristics of plants' diseases or growth become satirical through a metonymical description. This satirical use of Mediterranean plants concerns a historical fashion in garden art, revised by the English poet. Milton's use of vegetation is quite different and his paradise is planted with Mediterranean trees, "Cedar, and Pines, and Firr, and branching Palm" (Milton 2003, Book IV, 1. 139), "vine" (258) and "myrtle" (262) only situating it in the region of the world where the word was born-as "paradise" comes from a Persian word meaning garden. In Romantic poetry, plants evoke man's communion with nature and the "happy boughs", "forest branches and the trodden weed" described in Keats's (1987) Ode on a Grecian Urn speak about the role of art in the relationship between time and eternity. We might also think about Keats's Pot of Basil evoking life and death or Wordsworth's "yew-tree" speaking about time and eternity (Wordsworth et al 1983).

In William Carlos Williams' Paterson, the Mediterranean "laurel", "sand-pine" and "myrtle" face the American "temperate wild cactus" and "sumac", to speak about man's relationship with nature, and the "waist-thick sycamore", "locust-tree" and "palm-trees" denounce the exploitation of nature for money:

Money: Uranium (bound to be lead)

throws out the fire

— the radium's the credit - the wind in

the trees, the hurricane in the

palm trees, the tornado that lifts 
oceans. Paterson

Nigerian poet Niyi Osundare shows the damage done to Africa by exploitation and money.

[...] The desert marches towards the sea

Alas, the boundless rainforest of my youth

Has shrunk to a frightened eyebrow

On the forehead of the coast

Koko gba kokod (Osundare 2014).

The trees planted by settlers to make money like coffee or tea trees replaced Native cultures like yam-"yamfields succumbed to weeds and granaries" (Osundare 2000: xi). Tree exploitation transformed "an Eden long departed when the rainforest was terrifying green though each tree, each vine, each herb, each beast, each insect, had its name in the baffling baptism of Nature. [...] most of those trees so vivaciously native to this forest have met a rapid death in the hands of timber merchants [...]" (Osundare 2000: xii-xiii). Osundare's poems are an ecological shout for the preservation of the Earth through the land of Africa and at the same time they depict the beauty of a green Africa before the settlers had destroyed the Native plantations.

To explain the problem of deforestation, American poet Gary Snyder evokes the fate of Mediterranean forests. A list of Mediterranean plants is supposed to strike readers into awareness and to lead them to understand what is happening to Mediterranean vegetation: "Some 100 million acres of land once densely covered with pine, oak, ash, laurel, and myrtle, have only traces of vegetation" (Snyder 1990: 139). The list of precise Mediterranean plants is contrasted with the indefinite "traces of vegetation". He chooses the abundance of words to convey the abundance of vegetal life. Starting with a quotation from Plato's Critias, he builds his argument defending American forests by going back to the Mediterranean world, the cradle of civilization being also the first area hit by the destruction of its vegetation. A Mediterranean flower will even lend its colour to depict the purity of Arctic light in a poem: "lavender Arctic light" (Snyder 1990: 116). This oxymoronic light associating arctic ice and Mediterranean lavender, sounds like a quartering of nature, torn between its extreme landscapes.

From Pope's satirical painting of Mediterranean vegetation in English topiary art, to the poets' denunciation of tree exploitation, poetry in English use Mediterranean vegetation to build up a reflection on the relationship between man and nature. Men cutting trees to change them into human figures or to use them as resources are far away from the Romantic communion with nature; their acts are two expressions of a dominating perception of nature. Mediterranean trees are the instruments of an ecological denunciation and can also be a way of fighting against war. 


\section{Olive Trees in Palestinian Poetry: A Sign of Life on a Land in War}

Olive trees symbolize Mediterranean lands and have covered them for thousands of years, they are fraught with symbolism in the whole world. A symbol of peace in Jewish and Christian traditions, they are associated with light and the olive tree is the axis of the world in Islam (Chevalier and Gheerbrant 1982: 699). Devoted to Athena in Greece, they were nearly deified in the plain of Eleusis. In countries torn by war, olive trees recur to speak about a land of peace, ${ }^{5}$ particularly in Palestinian poet Mahmoud Darwish's work. One of his first collections of poems, published in 1964, is even entitled Awraq Al-Zaytun, which means Leaves of Olives. In his poem I come from there, he says:

"Mine is the moon at the far edge of the words,

And the bounty of birds,

And the immortal olive tree.

I walked this land before the Swords

Turned its living body into a laden table.

I come from there." War Poetry (n.d.)

The olive tree is associated with immortality, preceding the mention of violence through destroying swords metamorphosing this land of life (birds, olive tree and "living body") into "a laden table", that is only food to be consumed. In The Earth is Closing on Us, the olive tree is "planted" by Palestinian blood. The death of Palestinans as a people (We will die) is changed into the immortality of the olive tree:

We will die here, here in the last passage.

Here and here our blood will plant its olive tree.

In Victim, the "olive grove" is turned into "a red pool" suggesting that the olive grove is bleeding with "the blood of fifty victims":

The olive grove was always green;

It was, my beloved. But tonight

The blood of fifty victims

Has turned it into a red pool.

Please don't blame me If I can't come;

They've murdered me, too.

In Mahmoud Darwish's poetry, the olive tree is constantly associated with the Palestinian people's wounds and death. It becomes the metaphor of

\footnotetext{
${ }^{5}$ I am grateful to Rami Kimchi who guided me towards olive trees in Palestinian poetry and Israeli art through two films, among which his own film, Galia' s Wedding (1986), presented at the $9^{\text {th }}$ the Annual International Conference on Mediterranean Studies 21-24 March 2016, in Athens - and through a talk on Aegina Island.
} 
the Palestinian land and people living on like those eternal trees growing on the same land.

Even non-Palestinian poets associate the olive tree with Palestinian tragedy, like Brinda Runghsawmee, a poet from Mauritius, who opposes the olive trees of Palestine to war and violence:

The Hamas militant

Aims his foreign missile

Against Israel's border town

Full of olive trees

Swinging music in the gun-fire sky

Which cannot hide the blueness of lofty joy

Where arms do not exist. [The Love Birds]

The olive trees isolated in one line separate the stanza into two parts: one devoted to the violence of war and the other to "music", "joy", the blue colour of the Mediterranean sky, a world "where arms do not exist". It is as if the olive trees were the warrants of an eternal joy that no war could delete. They are the living element of safety as two lines suggest further on: "He leaves his post / Behind the safety of olive groves". A poet from afar echoes Palestinian poetry through the central role of olive trees. All those who fight for freedom recognize their own fight in the Palestinian poets' representation of their land through the eternity of olive trees. It is not by chance if it is an anti-apartheid Afrikaner poet, Breyten Breytenbach, who poetically sums up the strength of Darwish's poetry when he comments upon the Palestinian poet's last reading:

"The sun was setting, there was a soundless wind in the trees and from the neighbouring streets we could hear the voices of children playing. And for hours we sat on the ancient stone seats, spellbound by the depth and the beauty of this poetry. Was it about Palestine? Was it about his people dying, the darkening sky, the intimate relationships with those on the other side of the wall, 'soldier' and 'guest', exile and love, the return to what is no longer there, the memory of orchards, the dreams of freedom? Yes - like a deep stream all of these themes were there, of course they so constantly informed his verses; but it was also about olives and figs and a horse against the skyline and the feel of cloth and the mystery of the colour of a flower and the eyes of a beloved and the imagination of a child and the hands of a grandfather. And of death" (Ghazala's Weblog 2008).

Palestinian life as heard in Darwish's reading mixes the sounds of life and death but also of "olives and figs and a horse against the skyline and the feel of cloth and the mystery of the colour of a flower." The non human world surrounding the poet's voice shows the link between life and death, the intermingling of dying Palestinians and olives and figs, all informing a poetry in which destroying violence has never the upper hand as the olive 
trees remain, like an eternally protecting presence.

Thus poetry uses Mediterranean vegetation to depict a people's relationship with his land and this people's drama in the history of men. But Mediterranean plants may also be a mere metaphor of imagination.

\section{Mediterranean Plants in Travel Books and Gothic Novels as a Metaphor of Imagination}

In Ann Radcliffe's The Mysteries of Udolpho (1989/ 1794), landscape descriptions are often enriched by lists of tree species, flowers and particularly Mediterranean plants since several episodes take place in the Pyrenees, in Roussillon and also in Italy. Thus while following Emily's adventures, we can see "gloomy pine" (ibid: 1, 37) and "dark cypress" (ibid: 7), "palms" (ibid: 29), "cork-tree", "ilex", "oak and chestnut" (ibid: 30), "sycamore" (ibid: 36), "wild flowers and aromatic herbs", "cedars" (ibid: 37, 41). Sublime landscapes and Mediterranean luminous ones alternate: "lavender, wild thyme, juniper and tamarisk" (ibid: 42), introduce a touch of light into the dark gothic atmosphere. Mediterranean plants are clearly associated with imagination when the "balm-thyme and lavender" open on "recesses of fancy", and when "groves of orange and lemon perfumed the air", vineyards and the "hedges of flowering myrtle and pomegranate" (ibid: 55) alternate with the mountain reality of snowy peaks and dark forests.

Those Mediterranean vegetal references also appear as an element of imagination in some travel books like Mrs Boddington's Sketches in the Pyrenees. Her description of the landscape she imagines when she reaches the Port de Vénasque, reminds us of Ann Radcliffe's contrasting landscape and is saturated with Mediterranean plants suggesting that the mountain she had imagined was not the real one:

"How rejoiced I was to find myself there! And then, after the first glance, how disappointed! Yet I scarcely knew what I had expected: perhaps thirty degrees of Reaumur, sunny vales, citron groves, convent spires, towered cities in the distance, and spreading cork trees on the fore-ground. I cannot say, in short, what my visions may have been; but the reality was the austere and mighty Maladetta [...]; a scattering of dark pines, a limited horizon, and bleak peaks, white as itself. The other side of the mountains, the Spanish versant, had always seemed to me to carry with it a summer sound, - a date-and-fig and lemon odour; but an aspect of nature so unexpected, startled me out of my southern visions. (Boddington 1837: I, 159, author's underlining)

The arrival at the Port de Vénasque, a place of passage between France and Spain, appears as a confrontation between real sublime landscapes characterized by darkness and solitude, and luminous Spanish landscapes dominated by Mediterranean vegetation. Pines, lavender, thyme, orangetrees, "date-and-fig and lemon trees" appear as a projection of the writer's 
knowledge of Spain on a mountainous landscape metamorphosed by both real and imaginary fruit.

\section{Mediterranean Plants Telling a Story of Life, Death and Eternity in Some of Laurence Durrell's Works}

From The Egypt of The Alexandria Quartet to The Greek Islands, Durrell's work lives with Mediterranean places. His painting of Greek landscapes in The Greek Islands gives plants a prevailing role and it is not by chance if that journey through Greece ends on "Flowers and Festivals", a chapter associating Mediterranean flowers and myths. The book is at times a collection of stories told by Mediterranean vegetation. The writer tells the story of the "acanthus pattern which crowns the Corinthian columns", born from the gesture of the nurse of a young Corinthian girl who, after her death, had placed the treasures she loved in a basket and placed the basket on her tomb "over the roots of an acanthus plant" and placed a tile over the basket:

"When spring came the acanthus grew its leaves around the basket. The tile bent them back. The keen eye of Callimachus [...] fell upon this striking combination of forms and he adopted the motif for the Corinthian column he was just designing. So the head of this column the most perfect of the Greek style became a monument to a young girl who died some 2500 years ago. It is an attractive story" (Durrell 2002: 248-249)

The history of Greek art is presented as a story of death and life told by an acanthus whose wide leaves were fixed forever by a Greek sculptor to become the symbol of classical Greek art. A story of life, death and immortality is also told by another typically Mediterranean plant, the cypress, yet originating from the Himalayas. Durrell writes:

"This tree which runs wild in Greece and can be seen rising in groves from bare rock-faces over the blue sea, is really an exotic; I mean that it came originally from the Himalayas with the Phoenicians and was planted in Cyprus - that orphan among Greek islands - about I think $1000 \mathrm{BC}$, whence it worked its way into the Greek decor. Once adopted as a symbol of the immortal soul and equally of eternal death, the Greeks pressed it into more material service. Perhaps the impulse came from Egypt [where it was used for mummy-cases [...]. The island of Cyprus probably took its name from the tree" (Durrell 2002: 276-277)

A tree coming from the Himalayas was to become a symbol of Mediterranean landscapes evoking death and life. A symbol of the immortal soul in the Mediterranean world - present in the Garden of Eden situated in Jerusalem in the Canticles of Canticles (Sinclair 2000: 17), it also 
introduces Mediterranean vegetation into the map of the world since it gave its name to a Mediterranean island. And the banana-tree recurs in his work to evoke eternity:

I shall die one day I suppose

On this old Turkish house I inhabit:

A ragged banana-leaf outside and here

On the sill in a jam-jar a rock-rose (Durrell as cited in Keller-Privat 2015: 170)

Isabelle Keller-Privat writes that "the Tree of Idleness tries to capture another eternity, that of a peaceful death in the shadow of the banana-trees of the Turkish house, a desired death, reverberating from the first lines like a promise" (Keller-Privat 2015: 170, author's translation). She adds that "the banana-leaf and the rock-rose function both like traces of the vanished life and like clues of the life to come" (ibid.). Mediterranean vegetation becomes the metaphor of the dialogue established by the writer between past and future. Speaking about his future death is speaking about that Mediterranean vegetable life conveying light and peace.

\section{The Pomegranate and the Spanish City: Etymology as a Memory of Colonization in a Travel Text by N. Scott Momaday}

A Mediterranean vegetable element, a flower, tree or fruit, may be the opportunity for some writers to evoke history and the relationship of man with the land through colonization and movements from one continent to the other. In one of his essays relating a journey to Spain, Kiowa poet and novelist N. Scott Momaday (1998) mentions the origin of the name of Granada:

" 'I am going to Granada,' I said. 'Pomegranate,' the lady on my left said. 'Granada is the Spanish word for Pomegranate.' [...]

On the vast tableland of Castille-La Mancha there are abandoned haciendas in the foreground and castle ruins on the skyline. There is a hint of desolation and an unforgiving aspect to this land, a resonance of the Extremadura next door to the west, from which came so many of the Conquistadores, men peculiarly equal to the hardships of the New World. (Perhaps they bore seeds as well as swords. Along Coronado's route in Mexico and Arizona, I have seen hummingbirds at a hundred pomegranate trees)". (Momaday 1998: 148-149)

From the mere mention of a destination, a Spanish place-name, etymology and translation lead the writer to the story of colonization. Linguistic translation becomes translation in the original sense of the word, a translation of seeds from one continent to the other, allowing the poet to remember pomegranate trees in Arizona whereas he has just learnt that the 
name of the fruit was at the origin of the historical Spanish city. The short sentence inserted in parentheses-"Perhaps they bore seeds as well as swords"-, puts in parallel the weapons of destruction and the seeds of regeneration. The alliterative sound-"seeds"/"swords"-musically sums up the history of colonization paradoxically bringing life while destroying it. Moreover the evocation of the pomegranate shows the link between Spanish people invaded by the Moors and Native Americans invaded by Spanish Conquistadores. The fruit invites the reader to think about two visions of the world, the circle of violence being opposed to the movement of seeds.

Momaday's poetic vision of pomegranate as the visible and living image of colonization corresponds to a reality summed up by Alan Frost considering "the habit of plant transfer to be an important aspect of British imperialism in the second half of the eighteenth century" (Frost 2011: 74). All those who travelled to a geographical area unknown in their own country so far, brought back seeds of the plant species they wanted to introduce into Europe. The example of the establishment of a British settlement in Sydney is interesting as "immediately on landing", Frost says, "Governor Arthur Phillip began collecting seeds and specimens for the president of the Royal Society" (ibid: 58). The transfer of plants during voyages of discovery had not always mere scientific motivations. In some cases there might be a political aim and it was even sometimes linked with slavery. In all cases that made botanical gardens the reflexion of imperial domination as the whole world could symbolically grow in a Royal Garden where those plants were enclosed. Moreover the transfers of plants reflect the movements of populations and human history. The movements of trees and plants tell the history of human movements, wars and crusades, colonization or scientific voyages.

The presence of pomegranates in Arizona, alluded to by Momaday, evokes the reversed movements of those who, while conquering new territories, wanted to bring their home landscapes into the new country. Hence a sort of vegetable globalization materialized by the presence of the Mediterranean plants nearly everywhere in the world. Conversely some plants, which were going to become the symbol of a Mediterranean landscape, initially grew at the other end of the world like the cypress initially growing in the Himalayas or the eucalyptus initially growing in Australia. As for orange and fig trees, typically Mediterranean trees, they were transferred several times: orange-trees, first growing in China, were carried by Arabian caravans to Palestine, then imported to Europe during the Crusades before being transported to Brazil by Conquistadores and colonizers and from Brazil to Australia during some voyages of discovery. Plant transfers tell the history of men.

Botanical transfer raised a paradoxical question: it multiplied the possibilities of preservation of all species while standardizing some landscapes and bringing European vegetable landscapes into non-European countries. The Mediterranean world was thus exported through its seeds to the American continent before being in turn transferred onto the Austral 
one. In one short sentence, Momaday sums up the political dimension of botany during the European conquest.

\section{The Fig Tree in Wangari Maathai's Autobiography as the Explanatory Element of Interrelations on the Planet}

The 2004 Peace Nobel Prize winner Wangari Maathai, the woman who planted thousands of trees in Kenya with hundreds of Kenyan women and thus replaced the desert by a living forest, told her story in an autobiography, Unbowed: A Memoir (2006), in which she showed the link between all the elements of our world through a militant act centred on tree plantation. In her book, it is the fig tree that gives a fundamental message. The fig tree is first presented as a living sign of both fertility and mystery:

"The country was dotted with hundreds of huge mugumo, or wild fig trees, their bark the colour of elephant skin and thick, gnarled branches with roots springing out and anchoring the tree to the ground. Fig trees had great green canopies beneath which grew dense undergrowth. This tree's canopy was probably sixty feet in diameter and it produced numerous fruits that birds loved. When the fruit was ready you would find hundreds of birds feeding on them. The undergrowth of the fig tree was also very fertile because people did not cut anything near those trees but allowed the undergrowth to flourish. All this added to the tree's mystery" (Maathai, 2006: 44)

The description of the fig tree intermingles vegetable, animal and human lives, showing a chain whose basis is the fig tree feeding both human beings and birds and also filling out man's quest for mystery. It becomes the symbol of that interrelation, the conscience of which may help to preserve the planet and its inhabitants.

"I later learned that there was a connection between the fig tree's root system and the underground water reservoirs. The roots burrowed deep into the ground, breaking through the rocks beneath the surface soil and diving into the underground water table. The water travelled up along the root until it hit a depression or weak place in the ground, and gushed out as a spring. Indeed wherever these trees stood, there were likely to be streams. The reverence the community had for the fig tree helped preserve the stream and the tadpoles that so captivated me. The trees also held the soil together, reducing erosion and land slides. In such ways, without conscious or deliberate effort, these cultural or spiritual practices contributed to the conservation of biodiversity" (Maathai 2006:46)

By explaining to the reader the role of the fig tree in the ecosystem, Wangari Maathai highlights the fundamental role the Mediterranean tree has 
in the prevention of erosion and landslides as well as in the preservation of water. Linked with the preservation of the ecosystem and of life, the fig tree is also associated with the spiritual world since it is considered as "a tree of God" (ibid: 45). Her evocation of the fig tree shows the link between "cultural or spiritual practices" and "the conservation of biodiversity".

\section{Conclusion}

Nature imagery fills literature and Anglophone texts are full of landscape descriptions where vegetation plays an important part. Among all those literary plants, Mediterranean vegetation sends us back to the origin of our cultures, either the Greek one if we speak about the recent period of Antiquity, or Africa if we refer to the origins of mankind. Both areas, linked by the Mediterranean Sea, do not only offer us beautiful landscapes; they are in literary texts the projection of Man's life, history and questionings. Because olive-trees, lemon- and orange-trees speak to everybody, they are that simple natural element that may lead people to awareness, which may lead them to a sense of responsibility to a world in which they perceive the link with any non-human element. It may seem strange to see the mere mention of plants as activism. And yet the recurring use of Mediterranean trees and flowers in Anglophone literature draws the reader's attention to the link between nature and culture, the classical culture that Mediterranean plants suggest. Aware of this link, readers can question their own relationship with the non-human and with the world at large, they are led to a new sense of responsibility. Laurence Buell, in The Future of Environmental Criticism, writes:

"Criticism worthy of the name arises from commitments deeper than professionalism. Environmental criticism, even when constrained by academic protocols, is usually energized by environmental concern" (Buell 2005: 97, as cited in Slovic 2008: 3).

It is probably what that Mediterranean vegetable background suggests: an environmental concern energizing environmental awareness and sense of responsibility. Mediterranean plants as used by English-speaking writers suggest that environmental concern may use not only polemical discourse, not only paintings of the world's numerous ecological disasters, but simply the presence of the smallest plant speaking about beauty or life. Thanks to poets, whenever we see a branch of thyme or a blue wave of lavender, we may wonder whether those apparently frail plants are not explaining the world to us in order to lead us to awareness.

\section{References}

Bacon F (1627) Sylva Sylvarum: or A Naturall Historie. In Ten Centuries. London: William Lee. 
Baridon M (1998) Les jardins [Gardens]. Paris: Robert Laffont.

Blake W (1982) The Complete Poetry and Prose of William Blake. DV Erdman (Ed). USA: University of California Press.

Boddington Mrs (1837) Sketches in the Pyrenees 2 vol. London: Longman, Rees, Orme, Brown, Green and Longman.

Buell L (2005) The Future of Environmental Criticism: Environmental Crisis and Literary Imagination, Malden, MA: Blackwell.

Chevalier J, Gheerbrant A (1982) Dictionnaire des Symboles [Dictionary of Symbols]. Paris: Robert Laffont/Jupiter, coll. Bouquins.

Durrell L (2002) The Greek Islands, 1978. London: Faber and Faber.

Evans H, Leyris P (Eds) (1957) The Works of Shakespeare. Cambridge: Cambridge University Press.

Frost A (2011) The Antipodean Exchange: European horticulture and imperial designs. In DP Miller and PH Reill (Eds) Visions of Empire, Voyages, Botany, and Representations of Nature. Cambridge: Cambridge University Press.

Ghazala's Weblog (2008, August 22) Your blood will plant an olive tree and your people shall live in its shade.... Retrieved from http://bit.ly/29OWpRr.

Gillyflower (n.d.) In Library Index. Retrieved from http://bit.ly/29NZBM0. [Accessed 17 July 2016].

Keats J (1987) The Complete Poems. J Barnard (Ed). Harmondsworth: Penguin Books.

Keller-Privat I (2015) Between the Lines. L'écriture du déchirement dans la poésie de Lawrence Durrell [The writing of tearing in Lawrence Durrel's poetry]. Paris: Presses Universitaires de Paris Ouest.

Kerr J (1997) Shakespeare's Flowers. Mexico: Harpers and Collins Publishers.

Kunitz S (with Genin Lentine) (2005) The Wild Braid. A Poet Reflects on a Century in the Garden. New York, London: W.W. Norton \& Company.

Maathai W (2006) Unbowed: A Memoir. New York: Alfred A. Knopf, Random House.

Miller DP, Reill PH (Eds) (2010) Visions of Empire. Voyages, Botany and Representations of Nature, 1996. Cambridge: Cambridge University Press.

Milton J (2003) Paradise Lost. London: Penguin Books.

Momaday N S (1998) Granada: A Vision of the Unforeseen. In The Man Made of Words, 148-153. New York: St Martin's Griffin.

Osundare N (2000) The Eye of the Earth. Ibadan: Heinemann Educational Books.

Osundare N (2014, May-August) "Hole in the Sky", Choreo-poem. World Literature Today. Retrieved from http://bit.ly/29Hpdtf.

Pope A (1713, September 29) The Guardian $\mathrm{n}^{\circ} 173$.

Radcliffe A (1989) The Mysteries of Udolpho, 1794. Oxford: Oxford University Press.

Runghsawmee B (n.d.) The Love Birds. Retrieved from http://bit.ly/29O53OQ. [Accessed 25 March 2016].

Serres M (1974) Jouvences sur Jules Verne [Jouvences on Jules Verne]. Paris: Edition de Minuit.

Sinclair A (2000) Jardins de gloire, de délices et de Paradis [Gardens of Glory, Delights and Paradise]. Paris: J.C. Lattès.

Slovic S (2008) Going Away to Think. Engagement, Retreat, and Ecocritical Responsibility. Reno and Las Vegas: University of Nevada Press.

Snyder G (1990) The Practice of the Wild. Berkeley: Counterpoint.

War Poetry (n.d.) I come from there. Retrieved from http://bit.ly/29O530Q.

Williams WC (1963) Paterson. Retrieved from http://bit.ly/1NcoJge.

Wordsworth W, Coleridge S T, Owen JB (1983) Lyrical Ballads, 1798. Oxford: Oxford University Press. 